F. Robert Hunter - Assist. Professor, Islamic and Middle East History, Tulane University, New Orleans.

George W. Gawrych - Appointed to Middle Eastern and Mediterranean History Department, University of Kansas.

Rosal ind Gwynne

- Assist. Professor of Arabic, Asian Studies Committee, University of Tennessee, Knoxville.

Leonardo Al ishan

- Assist. Professor of Persian Language and Literature, University of Utah.

Adel Allouche

- Visiting Assist. Professor of Arabic Language, University of Utah, 1981-1982.

Raga i N. Mak.ar

- Visiting Assist. Librarian, Middle East Library, Marriott Library, University of Utah.

\title{
Fellowships and Grants Awarded
}

American Research Center in Egypt, 1981-82

- Michael L. Bates [ANS]: Catalogue of Coins Excavated at Fustat, 1964-1980. 1954.

-Joel S. Beinin [U/Michigan]: Labor and Politics in Egypt: 1936-

-Irene A. Bierman [U/Washington]: The Significance of the Zam-alif alif-lam Sequences.

-Gerhard H. Böwering [U/Pennsylvania]: Manuscript Research of Sulam i's Commentary on the Qur'an.

-Pierre J.E. Cachia [Columbia U]: The Beginnings of Modern Arabic Literary Criticism.

-Evelyn A. Early [U/Notre Dame]: Kiosk Pamphlets: Egyptian.

- Mahmood Ibrahim [UCLA]: Periodization in Medieval Islamic History:

A Theoretical Framework. Egypt.

- Barbara K. Larson [U/New Hampshire]: Rural Marketing Networks in

-William F. Macomber [St. John's U]: A Catalogue of Manuscripts in the Churches and Monasteries of the Coptic Church.

-Marilyn A. Mayers [Princeton U]: A Study in Cultural Change: The Development of Psychiatry in Egypt.

-Thomas M. Marett [Harvard U]: The 'Ulama and the Faithful in Contemporary Egypt: An Anthropological Approach.

-Timothy P. Mitchell [Princeton U]: Egyptian Society and its University, 1906-1936.

-Frank E. Vogel [Harvard U]:

Egyptian Law and Constitution.

- Peter von Sivers [U/Utah]: City and Countryside in the Middle East: History of a Precarious Relationship in Early Islamic Civilization, A.D. 750-1100.

-Steven H. Whiting [U/Michigan]: Stabilization, Growth and External Dependency: The Macroeconomics of Egypt after Nasser.

American Research Institute in Turkey, 1981-82

-Gerhard Böwering: tafsir.

-Daniel S. Goffman:

the 17 th Century.

-Irene Markoff: Folk Conceptual Systems in the Musical Culture of Turkish Minstrels. 
- Josephine E. Powel1: A Photographic and Descriptive Catalogue of the Flat-Woven Textiles of Turkey.

-John Spitzer: Melodic Elaboration in Turkish Art Music.

American University of Cairo

- Jonathan Bloom: Awarded the Cresswell Award for 1980.

Fulbright Program, 1981-1982

- Irene Bierman [Egypt/Turkey]: An Iconographic and Semiotic Study of the Meaning of the Zam-alif/alif-Zam Sequence.

- Miriam Cooke [Lebanon]: The Lebanese Civil War as a Turning Point in Lebanese Literature, with Emphasis on the Writings of Women.

-Evelyn Early [Syria]: Women's Therapeutic Action and Perceptions of Natural and Body Processes, Disease and Health, and the System of Popular (Baladi) Medicine vs. Cosmopolitan (Afrangi) Medicine.

-Fadwa El-Guindi [Egypt]: The Structural and Functional Role of the Contemporary Islamic Movement in Egypt.

Council for International Exchange of Scholars, 1981-82

-Abbas Daneshvari [Topanga, CA]: Iconography of Sacred Architecture in Islamic Egypt to A.D. 1517 - Cairo U/Helwan U, Egypt.

-Rolf W. Westphal [Houston, TX]: Lecture: Art, Architecture and Environmental Design - M.E. Technical U, Ankara, Turkey.

-Arthur E. Goldschmidt, Jr. [Pennsylvania State U]: Egyptian History, Late 18th Century to Present - Cairo U.

- Harold G. Marcus [Michigan State U]: Lecture: African History, Global Studies - U/Khartoum, Sudan.

- Howard A. Reed [U/Connecticut]: Ottoman Reform under Sultan Mehmet II - Boğazici U, Istanbul, Turkey.

-Kathleen Howard-Merriam [Bowling Green State U]: Strategies for Women's Development in Morocco - Rabat, Morocco.

-Eric M. Uslaner [U/Maryland]: Lecture: Legislative Politics, Political Parties and Elections - Hebrew U, Jerusalem.

-Marvin G. Weinbaum [U/I1linois]: U.S. Economic and Development Assistance to Egypt in the post-1973 Period. Lecture: Comparative Political Institutions, Politics of Food and Agricultural Development, American Government - Cairo U.

- Herbert F. Weiss [Brooklyn College, CUNY]: Lecture: Political Mobilization and Protest in Third World Countries with Emphasis on Africa - Boğazici U, Istanbul.

\section{Institute of Arab Studies, 1981-1982}

-Muhammad Hallaj: Palestine, a Bi-National Republic.

-Elias Khouri: Analysis of the Narrative in Arabic Prose.

-Leila Meo: The Lebanese National Movement.

-Norma Salem: Islam in the Political Thought of Bourguiba.

-Rosemary Sayigh: The Politicization of Palestinian Women in Lebanon: A Study of Change.

-Judith Tucker: Women and Change in Egypt, 1860-1914.

Social Science Research Council, 1981- Ph.D. Candidates

-Paul W. Blank [U/Texas]: Historical Geography of the Transforma$t$ ion of Upper Egypt, 1882-1922.

-Julia A. Clancy [UCLA]: Arms, Land and Trade in Nefta, Tunisia, 1840-1880. 
-Ruth F. Davis [Princeton U]: Malouf and the Renaissance of Musical Traditionalism in Tunis, from 1935 to the Present.

-Shahla Haeri [UCLA]: Mut'a Marriage in Contemporary Iran.

- Irene J. Markoff [U/Washington]: Conceptual Systems Underlying Turkish folk music.

-John M. Sadowski [UCLA]: Social Bases of State Formation in the Syrian Arab Republic, 1945-1970.

-Lee Strunin [Brandeis U]: The Role of the School in the Ethnic Integration of Students. [Israel]

\section{SSR Counc il - Post-Doctoral, 1981}

-Said A. Arjomand [SUNY/Stony Brook]: Religion, Ideology and Politics in Iran, 1848-1980.

-Allan Christelow [Bayero U/Kano, Nigeria]: Musl im Society, Politics and Law in Colonial Municipalities, 1865-1945.

-Virginia R. Dominquez [Duke U]: Folk Theories of Jewish Social Identity.

-Michael C. Hillman [U/Texas]: Poetry of Forugh Farrokhzad (19351967) and its Representativeness of the Views of Non-Establishment Intellectuals During the Period 1958 to 1977.

- Jacob Lassner [Wayne State U]: Legitimation of the CAbbasid Dynasty by Post-Revolution Historians.

-Judith E. Tucker [Harvard U]: Peasant and Lower-Class Urban Women in Egypt, 1860-1914.

\section{RECENT CONFERENCES ${ }^{\star \star}$}

$\star \star$ Correction to MESA BuzZetin, Vol. XV, No. 1, p. 71, July 1981: The Conference on Historical Interpretation and Self-View in Egypt and Israel, April 15, 1980, took place in Tel-Aviv, not New York.]

\section{Islam, Law and International Business in the Arab Middle East University of Chicago - April 16-18, 1981}

Fazlur Rahman:

[U/Ch icago]

Kha iry Tourk:

[111. Inst./Tech]

Farhat Ziadeh:

[U/Washington]

Owa is Succari:

[De Paul U]

Jeanet te Wakin:

Andrew C. Hess:

Ann Meyer:

Ismail Nazer:
Ownership and Legal Protection: Theoretical Issues.

Ownership and Legal Protection: Practical Issues.

Partnership and 0ther Forms of Association: Theoretical Issues.

Partnership and Other Forms of Association: PracPractical lssues.

Contracts: Theoretical Issues. [Columbia U]

Contracts: Practical issues. [ARAMCO]

Interest and Banking: Theoretical Issues. [U/Penn.]

Interest and Banking: Practical Issues.

\section{Eighth Levi Della Vida Conference \\ UCLA - May 1-3, 1981}

W. Montgomery Watt: Self-Images of Islam in the Koran and After. [U/Edinburgh]

Alford T. Welch: Muhammad's Understanding of Himself. [Michigan State]

William A. Graham: Islam in the Mirror of Ritual. [Harvard U] 